\title{
Chemo- and biostratigraphy of the Gaojiashan section (northern Yangtze platform, South China): a new Pc-C boundary section
}

\author{
A. Gamper ${ }^{1}$, U. Struck ${ }^{1}$, F. Ohnemueller ${ }^{2}$, C. Heubeck ${ }^{3, *}$, and S. Hohl ${ }^{3}$ \\ ${ }^{1}$ Museum für Naturkunde Berlin, Leibniz Institute for Evolution and Biodiversity Science, Invalidenstraße 43, \\ 10115 Berlin, Germany \\ ${ }^{2}$ Department of Geosciences and MARUM - Center for Marine Environmental Sciences, University of Bremen, \\ Leobener Str., 28359 Bremen, Germany \\ ${ }^{3}$ Institut für Geologische Wissenschaften, Freie Universität Berlin, Malteserstraße 74-100, 12249 Berlin, Germany \\ *Present address: Friedrich-Schiller-Universität Jena, Chemisch-Geowissenschaftliche Fakultät, \\ Institut für Geowissenschaften, Burgweg 11, 07749 Jena, Germany
}

Correspondence to: U. Struck (ulrich.struck@mfn-berlin.de)

Received: 19 February 2015 - Revised: 7 May 2015 - Accepted: 8 May 2015 - Published: 10 June 2015

\begin{abstract}
The widespread, terminal Ediacaran Dengying Formation ( $\sim 551-\sim 542 \mathrm{Ma})$ of South China hosts one of the most prominent negative carbonate carbon isotope excursions in Earth's history and thus bears on the correlation of the Precambrian-Cambrian boundary worldwide. The dominantly carbonate strata of the Dengying Formation are largely studied for their unique preservation of its terminal Ediacaran fauna but their geochemical context is poorly known. This study presents the first high-resolution stable isotope record $\left({ }^{13} \mathrm{C}, \delta^{18} \mathrm{O}\right)$ of calcareous siliciclastic shallow-water deposits of the Gaojiashan section (Shaanxi Province). The section includes (in ascending order) the Algal Dolomite Member, the Gaojiashan Member and the Beiwan Member of the Dengying Formation. Our data record a major $\delta^{13} \mathrm{C}_{\text {carb }}$ negative excursion to $-6 \%$ in the uppermost Gaojiashan Member which is comparable in shape and magnitude to the global Precambrian-Cambrian boundary negative $\delta^{13} \mathrm{C}$ excursion. Our data set is consistent with a "shallow-water anoxia" scenario which is thought to contribute to the "Cambrian explosion". The stratigraphic occurrence of Cloudina and a large negative $\delta^{13} \mathrm{C}$ excursion suggest that the Precambrian-Cambrian boundary is located near the top of the Gaojiashan Member and, consequently, that overlying carbonates and dolomites of the Beiwan Member are of earliest Cambrian age. Thus the Gaojiashan section may represent a new shallow-water section spanning the Precambrian-Cambrian boundary. Although bio- and chemostratigraphic data support this novel interpretation, we
\end{abstract}

cannot exclude the possibility that the key excursions may represent a local perturbation indicating a restricted-basin environment.

\section{Introduction}

The Ediacaran Period (ca. 635-542 million years before present (Ma) was a time of major global perturbation in biogeochemical cycles and the reorganization and evolution of metazoan life (Fike et al., 2006; Weber et al., 2007; Wang et al., 2012a). Following the end of the late Cryogenian Marinoan glaciation, which ended $\sim 635 \mathrm{Ma}$ (Condon et al., 2005), Ediacaran ocean chemistry and ecosystems experienced dramatic changes, climaxing in the "Cambrian explosion". Major steps in the evolution of metazoan life during this time interval can be linked to global negative carbonate carbon isotope excursions $\left(\delta^{13} \mathrm{C}\right.$ ) (Zhu et al., 2007; Shields-Zhou and Zhu, 2013). During the Ediacaran, a progressive oxygenation of the deep ocean associated with the rise of aquatic and atmospheric oxygen levels (Fike et al., 2006; McFadden et al., 2008) culminated in a subsequent transition from anoxic-ferruginous to oxic "modern" deep-oceanic conditions in the Cambrian (e.g. Och et al., 2013). However, intermittent euxinic water conditions and sporadic anoxic-ferruginous deep waters in continental margin settings were common until the early Cambrian coexisting with well-oxygenated waters (Canfield et al., 2008; 
a)

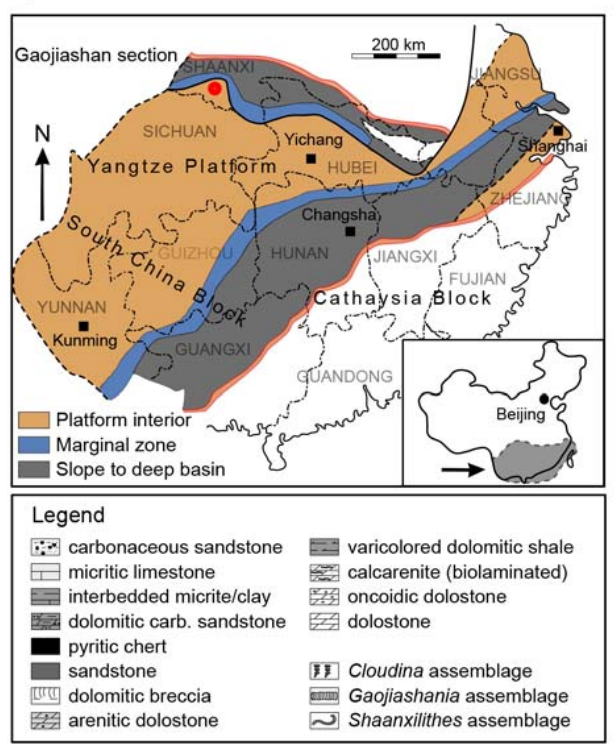

b)

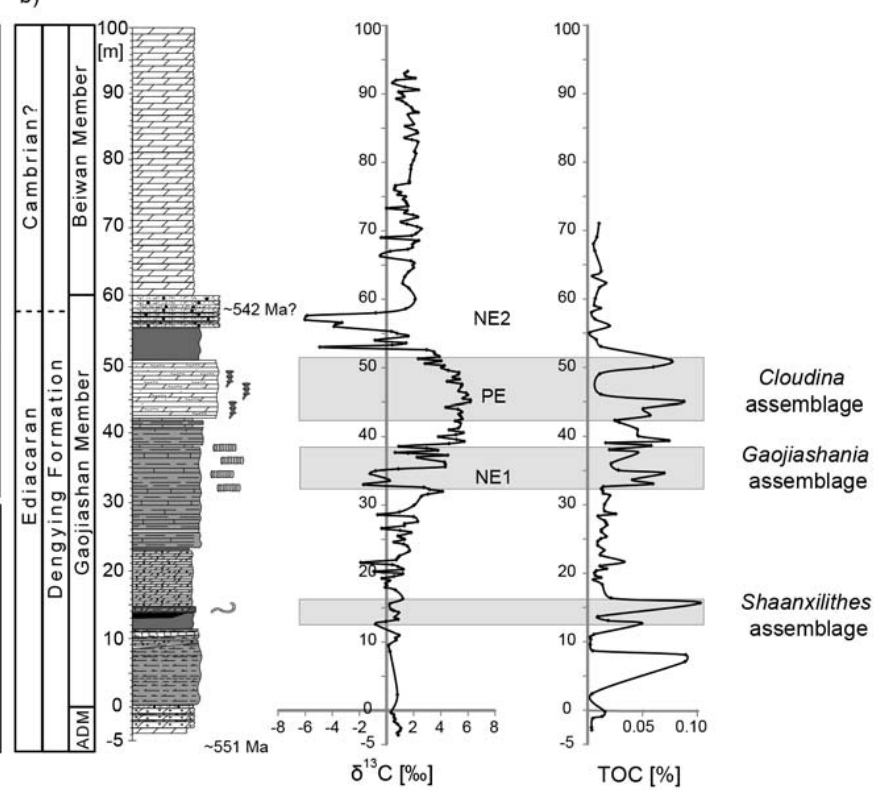

Figure 1. Palaeoenvironmental reconstruction of the Ediacaran Yangtze platform (modified after Guo et al., 2007; Cremonese et al., 2014) and the isotopic record of the Gaojiashan section. (a) Strata at the northern part of the platform display a coastal to shallow-shelf depositional environment. The Ediacaran slope faces south-east and grades into a deep-water basinal facies in the provinces Hubei, Hunan and Guizhou provinces (Vernhet et al., 2007). The Gaojiashan section discussed here (red circle) is located in Ningqiang County of southern Shaanxi Province. (b) Isotopic records of $\delta^{13} \mathrm{C}$ and TOC data correlated to the stratigraphical column. Stratigraphic column and fossil assemblages are modified after Q. Scouflaire (personal communication, 2012). Note the two prominent $\delta^{13} \mathrm{C}$ excursions (PE, NE2) linked to changes in corresponding TOC content. Shaanxilithes ningqiangensis, Gaojiashania and Cloudina in the Gaojiashan section occupy distinct zones which correlate with elevated TOC values. ADM: Algal Dolomite Member.

Li et al., 2010). However, the explicit identification and documentation of stratigraphic sections recording events across the Precambrian-Cambrian (Pc-C) boundary with little or no hiatuses remains challenging. Because numerous lithostratigraphic studies worldwide have documented widespread terminal Ediacaran relative sea level fall (Ishikawa et al., 2008), hiatuses or condensed sections are common; biostratigraphic positions and quality of index fossils are often controversial; and the validity of chemostratigraphic data is negatively affected by weathering, early- and burial diagenetic overprint, and alteration (Derry, 2010). In addition, the required age resolution of geochronological data is commonly insufficient. It is therefore widely accepted that only multi-disciplinary approaches can overcome the deficiencies of the bio-, lithoor chemostratigraphic record. Traditionally, the global correlation of the Pc-C boundary interval is based on biostratigraphic analyses. Narbonne et al. (1987) proposed the first occurrence of the ichnotaxon Treptichnus pedum as the index fossil of the earliest Cambrian. The earliest calcareous metazoans, e.g. Cloudina and Namacalathus have been shown to be of latest-Ediacaran rocks (Germs, 1972; Grotzinger et al., 2000; Kontorovich et al., 2008; Wood, 2011). Where trace fossils are missing or poorly preserved, chemostratigraphy has proven to be a powerful tool to complement biostratigraphy in Pc-C strata because terminal Ediacaran rocks record one of the largest global isotopic excursions in Earth's history. Negative $\delta^{13} \mathrm{C}$ excursions of up to $-12 \%$ o ( $\mathrm{Li}$ et al., 2013) in magnitude can be correlated worldwide, e.g. in South China (Jiang et al., 2007; Li et al., 2009), Oman (Amthor et al., 2003), Mongolia (Brasier et al., 1996), Brazil (Boggiani et al., 2010) and Siberia (Brasier et al., 1994). Several of the best preserved and most continuous successions across the Pc-C boundary are found on the Yangtze platform in South China (Zhu et al., 2007).

Thus, a combined interpretation of bio- and chemostratigraphic data can greatly contribute to identify the stratigraphic position of the Pc-C boundary where distinct bioand lithostratigraphic marker are absent. We present an integrated interpretation of carbon isotopic and palaeontological data from the literature, combined with the first high-resolution $\delta^{13} \mathrm{C}$ record from the Gaojiashan section (Fig. 1), Ningqiang County, southern Shaanxi Province (South China). We investigate the carbon $\left(\delta^{13} \mathrm{C}\right)$ and oxygen $\left(\delta^{18} \mathrm{O}\right)$ isotopic compositions as well as total organic carbon (TOC) contents of interbedded coastal carbonate-siliciclastic strata from the northern part of the NeoproterozoicDevonian Yangtze platform. 


\section{Geological setting and regional stratigraphy}

The Ediacaran Period of the Yangtze platform is divided into the basal Doushantuo Formation $(\sim 635-551 \mathrm{Ma})$ and the overlying Dengying Formation ( 551-542 Ma) (Condon et al., 2005; Zhu et al., 2007). Strata of the Doushantuo Formation directly cover Cryogenian glacial deposits. In Shaanxi Province, the thick dolostones and limestones of the Dengying Formation, representing a prograding platform facies environment associated with a sea-level regression, are unconformably overlain by the Cambrian Kuanchuanpu Formation (Zhu et al., 2003; Steiner et al., 2004). The Dengying Formation has received less attention than the underlying Doushantuo Formation, which has yielded numerous palaeontological, geochemical and stratigraphic investigations (Weber et al., 2007; Meyer et al., 2012; Cai et al., 2013). In part, this is because the Dengying Formation is up to $1000 \mathrm{~m}$ thick, consists nearly exclusively of variably dolomitized shallow-water platform carbonates dominated by monotonous shallow-marine and lagoonal-facies microbial boundstones, and lacks distinctive marker beds. It typically forms steep and subvertical cliffs and karsted surfaces. However, the middle to upper Dengying Formation at the northern margin of the Yangtze platform includes a siliciclastic interval, the Gaojiashan Member, which opens a rare preservational window into late Ediacaran evolution and has been investigated for its significant latest-Ediacaran metazoan fauna (Hua et al., 2001, 2003, 2005, 2007; Weber et al., 2007; Cai et al., 2010, 2011, 2012, 2013; Meyer et al., 2012).

The approximately $100 \mathrm{~m}$ thick Gaojiashan section (Fig. 1a) is located $\sim 4 \mathrm{~km}$ south of the town of Hujiaba. It exposes (from base to top) the Algal Dolomite Member, the Gaojiashan Member and the Beiwan Member of the Dengying Formation (Fig. 1b), which can be correlated with the Hamajing, Shibantan and Baimatuo members, respectively, of the same formation in the Yangtze Gorges-type area (Zhu et al., 2003; Cai et al., 2010). The interbedded siliciclastic and carbonate units at the Gaojiashan section were deposited in a passive-margin setting in a dominating coastal to shallow-water carbonate environment affected by periodic siliciclastic sedimentation (Zhu et al., 2003; Weber et al., 2007). The Dengying Formation in Ningqiang County is thought to have been deposited between 551 and $541 \mathrm{Ma}$ (Condon et al., 2005; Cai et al., 2010, 2011) and thus records the latest Ediacaran, immediately prior to the onset of the base-Cambrian radiation of early animals. The basal Algal Dolomite Member predominantly consists of dolostones with abundant dissolution features (Zhu et al., 2007; Cai et al., 2010). It is separated from interbedded fine-grained siliciclastics and carbonates of the overlying Gaojiashan Member by an erosional unconformity (Zhu et al., 2007). The Gaojiashan Member at this locality reaches approximately $60 \mathrm{~m}$ thickness and can be subdivided into five mappable units. The basal unit, approximately $10 \mathrm{~m}$ thick, consists of dolomitic green to red shales. It is gradationally overlain by a shaly $\sim 8 \mathrm{~m}$ thick dolomudstone which is glauconitic and phosphatic near its base and contains mass accumulations of Shaanxilithes ningqiangensis; it coarsens up into a dolograinstone of a tidal facies. This unit, in turn, is overlain by laminated, shale-clast-bearing green pyritic siltstone interbedded with some grey nodular dolomudstone approximately $18 \mathrm{~m}$ thick. Its upper part, about 5-8 m thick, contains the so-called Gaojiashan biota, comprising Gaojiashania and Conotubus. This unit coarsens upward into an impure, biolaminated, dolomitized calcarenite $\sim 8 \mathrm{~m}$ thick which displays oncoids, reworked microbial laminations and trace fossil horizons. A distinctive, medium- to coarse-grained, granule-bearing, well-sorted, channelized and cross-bedded dolomitic and quartz-rich arkose, coarsening-upward and approximately $9 \mathrm{~m}$ thick, marks the top of the Gaojiashan Member. Its top is gradationally overlain by silty dolomites and nodular limestones of the Beiwan Member. Overall, the lithologies, sedimentary structures and inferred facies successions are consistent with a regressive sub- to lower intertidal environment into which a delta prograded. Three important fossil taxa have been described from the Gaojiashan Member (Hua et al., 2005; Weber et al., 2007; Cai et al., 2010, 2012, 2013; Meyer et al., 2012): Shaanxilithes ningqiangensis, Gaojiashania and Cloudina. The latter is one of the earliest biomineralizing organisms and is used to correlate late Ediacaran (550-540 Ma) strata (Shields-Zhou and Zhu, 2013) in, for example, Namibia (Germs, 1972), Oman (Amthor et al., 2003), Canada (Hofmann and Mountjoy, 2001) and Paraguay (Warren et al., 2011). The Gaojiashan Member is capped by a distinct granular arkose with carbonate-dolomite cement. Cai et al. (2010) refer to this lithology as a "sandstone-conglomerate unit" which thins from west to east in the Gaojiashan outcrop belt, and thus implies a western provenance. The overlying Beiwan Member consists of thick-bedded dolomitized limestone and varies widely in thickness (Cai et al., 2014). Cai et al. (2010) report Cloudina from this unit at this section, whereas more recent reports describe Cloudina only in the upper Gaojiashan Member (Guo et al., 2012; Meyer et al., 2012; Cai et al., 2014).

\section{Analytical methods and materials}

Approximately 200 samples spaced about 0.3 to $1 \mathrm{~m}$ apart were collected along a traverse ca. $100 \mathrm{~m}$ long from the "Gaojiashan section" at $32^{\circ} 57^{\prime} 29.48^{\prime \prime} \mathrm{N}, 106^{\circ} 27^{\prime} 33.80^{\prime \prime} \mathrm{E}$. To recognize and reduce the effects of a diagenetic overprint, we analysed 23 petrographic thin sections, cathodoluminescent images and oxygen isotopic composition of selected samples.

After removing weathered surfaces and macroscopically visible veins from samples, cleaned samples were ground to powder using an agate mill and analysed for their bulk $\delta^{13} \mathrm{C}$ 
and $\delta^{18} \mathrm{O}$ isotope composition. Stable isotope ratio measurements were performed at the Museum für Naturkunde Berlin using a Thermo Finnigan GasBench II coupled online with a Thermo Finnigan Delta V isotope ratio mass spectrometer. Approximately 100-400 $\mu \mathrm{g}$ of sample material was put into a clean $10 \mathrm{~mL}$ Exetainer. After sealing the Exetainer with a septum cap the remaining air was removed by flushing the Exetainer with $\mathrm{He}$ for $5 \mathrm{~min}$ at a flow of $100 \mathrm{~mL}$ per minute. After flushing, approximately $30 \mu \mathrm{L}$ of anhydrous phosphoric acid was injected through the septum into the sealed Exetainer by using a disposable syringe and allowed to react for approximately $1.5 \mathrm{~h}$. Reference gas was pure $\mathrm{CO}_{2}$ from a cylinder calibrated against the Vienna Pee Dee Belemnite (VPDB) standard by using IAEA reference materials (NBS 18 , NBS 19). Isotope values are shown in the conventional delta notation $\left({ }^{13} \mathrm{C}\right.$ and $\left.\delta^{18} \mathrm{O}\right)$ in per mil (\%o) versus VPDB. Reproducibility of replicate measurements of lab standards (Jurassic limestone) is generally better than $0.10 \%$ o (1 standard deviation).

After decalcifying the sample powder with $2 \mathrm{M} \mathrm{HCl}$, total organic carbon content (TOC) was calculated by elemental analysis-isotope ratio mass spectrometry (EA-IRMS) using a Thermo Finnigan MAT V isotope ratio mass spectrometer coupled to a Thermo Flash EA 1112 elemental analyser via a Thermo Finnigan Conflo III interface at the Museum für Naturkunde Berlin. The analytical error is within $3 \%$ of the material analysed.

Rare earth element and yttrium $(\mathrm{REE}+\mathrm{Y})$ concentrations were analysed by the geochemistry group at Freie Universität Berlin. Following the method described in Hohl et al. (2015), $20 \mathrm{mg}$ rock powder of three selected samples (Table 2) was treated with $3 \mathrm{M}$ acetic acid for at least $12 \mathrm{~h}$; the supernatant was centrifuged and filtered. The supernatant was then dried down and convert into nitric form by adding $1 \mathrm{~mL}$ of $3 \mathrm{M}$ $\mathrm{HNO}_{3}$. The samples were then redissolved in $0.28 \mathrm{M} \mathrm{HNO}_{3}$, weighed, diluted $1: 20000$ and, for instrumental drift correction, doped with solutions of $2 \mathrm{ppb}$ In and $1 \mathrm{ppb} \mathrm{Tl}$ for elements analysed in low-resolution mode (REE, $\mathrm{Y}, \mathrm{Rb}, \mathrm{Pb}, \mathrm{Sr}$, $\mathrm{Mo}, \mathrm{Cd}, \mathrm{In}, \mathrm{Tl}, \mathrm{P}, \mathrm{Th}, \mathrm{U})$ and $12.5 \mathrm{ppb}$ Co for elements analysed in medium-resolution mode $(\mathrm{Mg}, \mathrm{Al}, \mathrm{Ca}, \mathrm{Mn}, \mathrm{Cr}, \mathrm{Fe}$, $\mathrm{Co}, \mathrm{K}, \mathrm{V}, \mathrm{Zn}, \mathrm{Ti})$. REE $+\mathrm{Y}$ analysis was performed in lowresolution mode on a Thermo Fisher Scientific Element XR sector-field ICP-MS using a Scott-type quartz spray chamber and a $100 \mu \mathrm{Lmin}^{-1}$ nebulizer. Sample time was $120 \mathrm{~s}$ with 20 samples per peak and 60 total scans. With this analytical setup tuning generally yielded low oxide rates of 2$5 \% \mathrm{CeO}^{+}$and less than $1 \% \mathrm{BaO}^{+}$. Element concentrations were evaluated by external calibration method to the matrixmatching CAL-S carbonate standard (Yeghicheyan et al., 2003). We corrected for instrument drift using internal standard solutions containing In and Tl. Background corrections were performed by subtraction of the raw intensities of aspirated $0.28 \mathrm{~m} \mathrm{HNO}_{3}$. The analytical precisions were between 2 and $7 \%$ RSD for REE and Y. The detection limit of light rare earth elements (LREE) was 100-620 $\mathrm{pg} \mathrm{g}^{-1}$, and that of heavy rare earth elements (HREE) was $16-240 \mathrm{pg} \mathrm{g}^{-1}$. Procedural blanks of REE $+Y$ were negligible (for further details, see Hohl et al., 2015).

\section{Results}

Geochemical data are summarized in Tables 1 and 2.

\subsection{Isotope and TOC data}

The carbon isotope composition of the Gaojiashan section shows two negative excursions (NE1 and NE2) separated by one positive excursion (PE; Fig. 1b; for further information see Table 3 in the Supplement). The first negative excursion (NE1) is preceded by relatively uniform $\delta^{13} \mathrm{C}$ values $(\sim 0.7 \%$ o $)$ in the basal part of the section with corresponding $\delta^{18} \mathrm{O}$ values ranging from -2 to $0 \%$ and TOC data $<0.01 \%$ (Fig. 1b). TOC concentrations reach highest values $(\sim 0.1 \%)$ within the Shaanxilithes ningqiangensis assemblage zone. Isotopic values of overlying micritic limestones begin a positive $\delta^{13} \mathrm{C}$ trend to $4 \%$, whereafter they are truncated by the short but sharp negative excursion NE1 to values of $-2 \%$. Concurrently, TOC increases to $>0.01 \%$ along with in situ buried and pyritized Gaojiashania-group fossils reported from beds correlative with NE1 (Cai et al., 2010). $\delta^{18} \mathrm{O}$ values do not correspond to the negative trend of $\delta^{13} \mathrm{C}$ data (NE1) but steadily decrease to $-6 \%$ in overlying strata. In contrast to $\delta^{13} \mathrm{C}$ data, $\delta^{18} \mathrm{O}$ values do not correspond to the trend of NE1 but steadily decrease to $-6 \%$ in overlying strata. Following NE1, biolaminated calcarenites of the middle Gaojiashan Member host a positive excursion (PE) to $6 \%$ associated with Cloudina and accompanied by increasing TOC content $(\sim 0.1 \%)$. A subsequent large $\delta^{13} \mathrm{C}$ negative decrease to $-6 \%$ (NE2; drop of $\sim 10 \%$ o) and the last repeatedly documented occurrence of Cloudina, along with decreasing TOC values $(\sim 0.01 \%)$, mark the boundary interval from the Gaojiashan to the Beiwan Member. $\delta^{18} \mathrm{O}$ values do not trace NE2 but show a decrease to $-9 \%$ at the onset of NE2 and recover to $\sim-3.5 \%$ o for the remaining section prior to the return of $\delta^{13} \mathrm{C}$ compositions to $\sim 0 \%$. Above NE2, $\delta^{13} \mathrm{C}$ values stabilize around $2 \%$ in the uppermost coarse-grained sandstone beds and stay largely invariant throughout the overlying dolomites.

\subsection{Rare earth element and yttrium (REE+Y) data}

Three samples ( $\mathrm{Gj}$ 56.3, 56.6, 57.0) were analysed for their REE $+Y$ concentration. Data are normalized relative to post-Archean Australian Shale (PAAS) (McLennan, 1989). Values for $\mathrm{Ce} / \mathrm{Ce}^{*}$ and $\mathrm{Eu} / \mathrm{Eu}^{*}$ were calculated following Lawrence and Kamber (2006): $\mathrm{Ce} / \mathrm{Ce}^{*}=\mathrm{Ce}_{N} /\left(\operatorname{Pr}_{N}{ }^{*}\right.$ $\left.\operatorname{Pr}_{N} / \mathrm{Nd}_{N}\right)$ and $\mathrm{Eu} / \mathrm{Eu}^{*}=\mathrm{Eu}_{N} /\left(\mathrm{Sm}_{N}^{2} * \mathrm{~Tb}_{N}\right)^{1 / 3}$. These equations avoid using $\mathrm{La}$ and $\mathrm{Gd}$ to distinguish real anomalies on $\mathrm{Ce}$ and $\mathrm{Eu}$ and not anomalies caused by an overabundance of the directly neighbouring elements (Ling et 


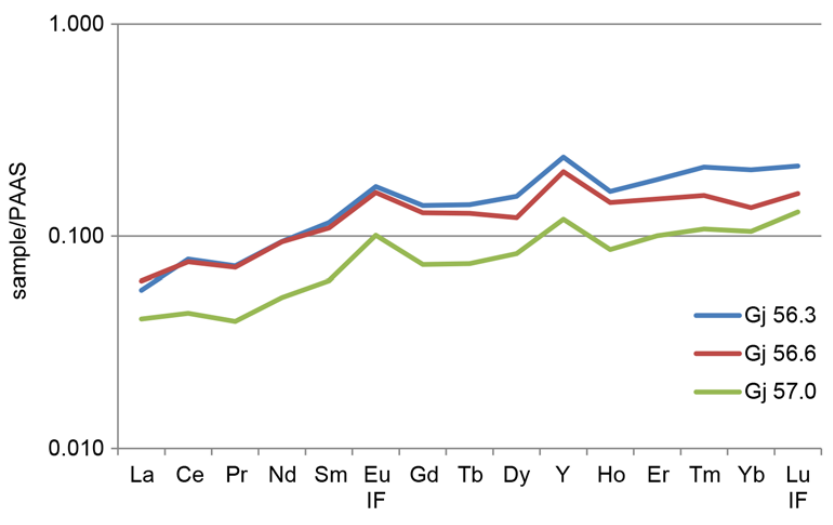

Figure 2. PAAS normalized REE+Y distribution patterns of samples $\mathrm{Gj}$ 56.3, 56.6 and 57.0 of the uppermost Gaojiashan Member at Gaojiashan section. Samples show a characteristic seawater-like signature with HREE over LREE enrichment and a distinct Y / Ho anomaly.

al., 2013). However, several publications have shown that Eu anomalies may be compromised by analytical artifacts of interfering $\mathrm{BaO}^{+}$molecules on Eu which cannot be completely resolved by ICP measurements (e.g. Dulski, 1994). Therefore $\mathrm{Eu} / \mathrm{Eu}^{*}$ anomalies are not discussed here.

The three analysed sample leachates reveal typical seawater-like REE $+\mathrm{Y}$ patterns with relative enrichment of HREE over LREE (PrPAAS / YbPAAS between 0.35 and 0.52 ) and positive normalized $\mathrm{Y} / \mathrm{HoPAAS}$ anomalies varying around 1.4 (Table 2, Fig. 2). Furthermore all samples show constant positive $\mathrm{Ce} / \mathrm{Ce}^{*}$ anomalies of the order of 1.4 , indicating a relative excess of cerium to its neighbouring LREE.

\section{Discussion}

\subsection{Preservation of primary isotopic signatures}

Carbon and oxygen isotopes of sediments are widely used as sensitive indicators of diagenetic overprint because their isotopic values change characteristically during progressive (burial) diagenesis (Knauth and Kennedy, 2009). Thereby $\delta^{18} \mathrm{O}$ values $<-10 \%$ and a positive correlation between $\delta^{13} \mathrm{C}$ and $\delta^{18} \mathrm{O}$ are usually interpreted as evidence for alteration (Derry, 2010; Li et al., 2013). Knauth and Kennedy (2009) proposed that numerous Neoproterozoic negative $\delta^{13} \mathrm{C}$ anomalies were caused by meteoric alteration processes. However, Macouin et al. (2012) pointed out that a co-variation between the systems due to meteoric alteration had to involve terrestrial phytomass and organic-rich soils in which mineralization could occur. For this, no Neoproterozoic evidence exists.

We argue that the obtained isotopic data set at Gaojiashan section represents a primary marine isotope signature for the following reasons. $\delta^{18} \mathrm{O}$ data range from -9 to $0 \%$ (average

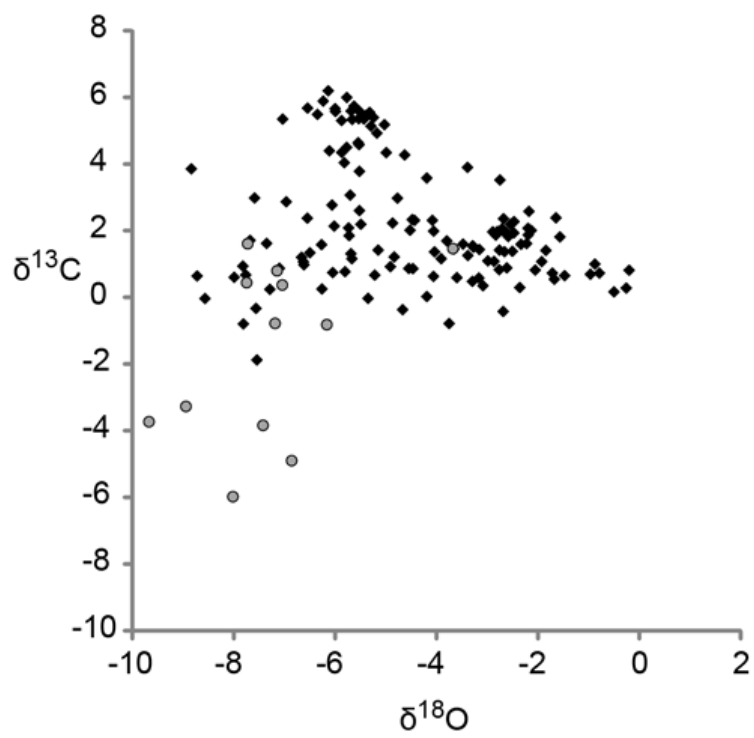

Figure 3. Cross plot of $\delta^{18} \mathrm{O}$ and $\delta^{13} \mathrm{C}$ of samples from the Gaojiashan section to estimate alteration effects. Grey circles represent values within the range of the negative $\delta^{13} \mathrm{C}$ excursion NE2. No significant correlation indicating diagenetic resetting is obvious.

$\delta^{18} \mathrm{O}=-5 \%$; Table 1) and therefore fail to fulfill the diagenetic criteria stated above. $\delta^{18} \mathrm{O}$ vs. $\delta^{13} \mathrm{C}$ (Fig. 3 ) shows no correlation. Especially $\delta^{13} \mathrm{C}$ and $\delta^{18} \mathrm{O}$ data near the prominent negative $\delta^{13} \mathrm{C}$ excursion (grey circles, Fig. 3) lack any correlation which would be expected if alteration had been a dominant post-depositional process during late open-system diagenesis. If fluid alteration had been present at all, it was presumably too weak to re-equilibrate the $\delta^{18} \mathrm{O}$ isotopic composition of the mineral phases and thus too small to significantly alter the $\delta^{13} \mathrm{C}$ composition of the rock (Kaufman and Knoll, 1995).

Very early closed-system diagenesis could have occurred but most likely did not affect the isotope values.

Furthermore, strata comprising NE2 for which a diagenetic overprint could be suspected show a distinct marine seawater-like REE $+Y$ pattern. There is no indication for post-depositional alteration effects such as an increase in LREE or a decrease in the Y / Ho ratio (Northdurft et al., 2004). Instead obtained REE $+Y$ values are consistent with open-ocean seawater-like REE signatures showing HREE enrichment over LREE and MREE and a characteristic positive Y / Ho anomaly (Fig. 2; e.g. Bau and Dulski, 1996). If it is accepted that the REE+Y patterns record primary seawater signatures, it is most likely that the $\delta^{13} \mathrm{C}$ and $\delta^{18} \mathrm{O}$ values represent original marine signals too. Therefore, we argue for a primary oceanic signal of isotope data.

\subsection{Correlation of strata in the Ningqiang area}

Lithostratigraphic correlation of late Ediacaran strata in southern Shaanxi Province remains under debate due to large 




Figure 4. Comparison of simplified litho- and biostratigraphic columns of the Lijiaguo section (a, b) and the Gaojiashan section (c-e) in Ningqiang County. Stratigraphic columns reported in the literature from both sections show significant stratigraphic uncertainties. Blue bars represent the occurrence of Cloudina used for correlation of columns shown. At Lijiaguo section (ca. $20 \mathrm{~km} \mathrm{NW}$ of Gaojiashan section) the assignment of dolostones to either the Beiwan Member (a) or the Gaojiashan Member (b) is unresolved. Note that the marker horizon ("sandstone-conglomerate unit") of Cai et al. (2010) is absent at Lijiaguo section. At Gaojiashan section (c-e), the stratigraphical occurrence of Cloudina is probably limited to the upper Gaojiashan Member (d, e). Chemostratigraphic data (Fig. 12, this study) suggest that the Beiwan Member is of lower Cambrian age (e). Dashed lines represent assumed contacts.

lateral thickness changes, limited outcrop and structural separation of the folded and faulted outcrop belts (Weber et al., 2007; Cai et al., 2010, 2014); in addition, chemostratigraphic work in Ningqiang County is sparse (Zhu et al., 2007; Guo et al., 2012).

Cai et al. (2010) correlate seven sections of the Dengying Formation across the Ningqiang area showing significant regional variations in the thickness of the Gaojiashan Member. Cai et al. (2010) based their correlation on the occurrence of Shaanxilithes ningqiangensis in the lower Gaojiashan Member and on the presence of a sandstone-conglomerate unit at its top. However, because the marker horizon is absent in three of these seven measured sections, its value is less than perfect, and thus the regional correlation of the upper Gaojiashan Member remains ambiguous.

Large thickness variations in the Beiwan Member dolostones from > $300 \mathrm{~m}$ (Hua et al., 2007; Weber et al., 2007; Zhu et al., 2007) to zero (Hua et al., 2003, 2005; Cai et al., 2014) also demonstrate the inadequacy of lithostratigraphy as a reliable correlation tool. Thick dolostones were variably and inconsistently assigned either to the Beiwan Member or the Gaojiashan Member in the literature (Hua et al., 2007; Weber et al., 2007; Guo et al., 2012; Cai et al., 2010, 2013, 2014). As a case in point, the Lijiaguo and the Gaojiashan sections (Fig. 4) graphically illustrate the stratigraphic uncertainties of the Precambrian-Cambrian boundary intervals in the Ningqiang area.
At Lijiaguo section, the sandstone-conglomerate unit is absent (Cai et al., 2010) and the dolostone overlying the middle part of the Gaojiashan Member is assigned to either the Beiwan Member (Hua et al., 2007; Weber et al., 2007; Cai et al., 2010) (Fig. 4a) or to the upper part of the Gaojiashan Member (Cai et al., 2013, 2014; Fig. 4b).

Discrepancies concerning the biostratigraphic occurrence of Cloudina complicate the stratigraphic framework at Gaojiashan section as well (Fig. 4c-e). While Cai et al. (2010) reported the occurrence of Cloudina in both the Gaojiashan and Beiwan Members (Fig. 4c), Cloudina is confirmed in more recent publications only for the Gaojiashan Member (Guo et al., 2012; Cai et al., 2013, 2014) (Fig. 4d); this is consistent with our own observations (Fig. 4e).

Lastly, the lithological nature of the contact between the Dengying Formation and the overlying Kuanchuanpu Formation is highly variable among sections. Whereas at the $\mathrm{Li}-$ jiaguo section Dengying dolostones are overlain by cherts (Fig. 4a, b), Dengying dolostones at the Shizhonggou section are overlain by limestones containing small shelly fossils, both assigned to the Kuanchuanpu Formation (Steiner et al., 2004). Because of the lack of distinct lithological marker horizons, radiometric age data and detailed chemostratigraphical analyses, the age of Beiwan dolostones overlying the Cloudina assemblage at Gaojiashan section and its uppermost unit, the sandstone-conglomerate unit, is hence uncertain. 
Thus, the highly variable stratigraphy between and within the outcrop belts demonstrates that biostratigraphic and lithological description alone is insufficient to reliably assign strata stratigraphically, and thus prerequisites for regional and supra-regional correlation require the integration of chemostratigraphy and geochronological data.

\subsection{Chemostratigraphic correlation of the Gaojiashan section}

Carbon isotope data of the Gaojiashan section show two prominent features: first, a positive $\delta^{13} \mathrm{C}$ excursion (PE) associated with the appearance of Cloudina fossils in the upper Gaojiashan Member; second, a large negative $\delta^{13} \mathrm{C}$ excursion (NE2) in the uppermost Gaojiashan Member. We suggest that the Gaojiashan section represents the Pc-C boundary interval and that NE2 correlates with the global negative $\delta^{13} \mathrm{C}$ excursion associated with the approximate beginning of the lower Cambrian (Brasier et al., 1994, 1996; Narbonne et al., 1994; Amthor et al., 2003; Kaufman et al., 2006; Ishikawa et al., 2013; Li et al., 2013).

This hypothesis is supported by the following evidence:

1. $\delta^{13} \mathrm{C}$ values of the lower Gaojiashan Member are in agreement with previously reported data from Guo et al. (2012) and other Dengying Formation shallow-water settings of South China (Jiang et al., 2007; Wang et al., 2012b). Additionally, $\delta^{18} \mathrm{O}$ values near $-5 \%$ match late Ediacaran $\delta^{18} \mathrm{O}$ data from the Yangtze platform (Yang et al., 1999; Jiang et al., 2007).

2. The presence of Cloudina fossils in the upper Gaojiashan Member is a global marker for terminal Ediacaran strata because Cloudina is known to become extinct just prior to the Pc-C boundary event (Amthor et al., 2003). Their association with a positive $\delta^{13} \mathrm{C}$ interval preceding the prominent Pc-C negative $\delta^{13} \mathrm{C}$ isotopic excursion is widely documented at late Ediacaran sections on the Yangtze platform (Zhu et al., 2003, 2007; Zhou and Xiao, 2007) as well as in Oman (Amthor et al., 2003). Additionally, ${ }^{87} \mathrm{Sr} /{ }^{86} \mathrm{Sr}$ ratios between $\sim 0.708$ and $\sim 0.709$ reported from this part of the section (Ohnemueller et al., 2013) suggest open-ocean conditions and agree with global late Ediacaran sections (Halverson et al., 2007; Sawaki et al., 2014).

3. The positive excursion PE is followed by a decrease in carbon isotope values with a minimum at $-6 \%$ (NE2). Magnitude and shape of NE2 find significant equivalents in other Pc-C boundary sections (e.g. Amthor et al., 2003; Zhu et al., 2007; Ishikawa et al., 2008; Li et al., 2013; Fig. 5). Nevertheless, several small late Ediacaran carbon isotope excursions preceding the Pc-C boundary excursion exist, e.g. in the Stirling Quartzite, SW Laurentia (Corsetti and Kaufman, 2003; Kaufman et al., 2007; Verdel et al., 2011), and the Krol D Formation of the Lesser Himalaya, northern India (Kaufman et al., 2006); however they are smaller in magnitude and maybe of local extent. No other negative $\delta^{13} \mathrm{C}$ excursion of an offset of $\sim 10 \%$ is known from the Dengying Formation; thus, NE2 at Gaojiashan section likely records global perturbations of the carbon cycle during the $\mathrm{Pc}-\mathrm{C}$ boundary transition.

4. The regression (Gaojiashan Member)-transgression (Beiwan Member) cycle related to the negative $\delta^{13} \mathrm{C}$ excursion (NE2) at Gaojiashan section is in agreement with the globally observed major late Ediacaran regression-early Cambrian transgression character at the Pc-C boundary (Ishikawa et al., 2008).

Thus, we propose a correlation of the Gaojiashan section to worldwide Pc-C boundary sections. To illustrate our hypothesis, we compare the chemostratigraphy of the Gaojiashan section to global data sets (Amthor et al., 2003; Zhu et al., 2003; Shields-Zhou and Zhu, 2013) based on the two aforementioned $\delta^{13} \mathrm{C}$ excursions (PE, NE2) and the known range of the Cloudina assemblage (Fig. 5).

\subsection{Causes of isotopic variations at Gaojiashan section and their palaeoenvironmental implications}

Two alternative scenarios may have caused isotopic variations at Gaojiashan section. The creation of a negative carbon isotopic trend to $-6 \%$ (NE2) requires the formation of a strongly ${ }^{13} \mathrm{C}$-depleted pool of dissolved inorganic carbon (DIC). High (surface-water) bioproductivity, suggested by two prominent fossil assemblages (Gaojiashania and Cloudina), contributed to the evolution of PE. Resulting increasing organic matter export to depth thus provoked high remineralization rates and oxygen depletion in bottom waters. Anoxic conditions in deep waters and in the sediment enabled the oxidation of organic matter via, for instance, sulfate-reducing bacteria, which contributed to a ${ }^{13} \mathrm{C}$-depleted deep-water DIC pool, a scenario similarly postulated for the Ediacaran Shuram-Wonoka anomaly (Jiang et al., 2007; McFadden et al., 2008). A subsequent shoaling of the chemocline and its chemical consequences likely strengthened water column stratification and led to vertical isotopic gradients (Jiang et al., 2007) and to a decrease in sedimentary $\delta^{13} \mathrm{C}$ values. A subsequent rise in anoxic bottom waters to shallowwater depths provoked a decrease in $\delta^{13} \mathrm{C}$ values to $-6 \%$ o (NE2) as it is enriched in ${ }^{13} \mathrm{C}$-depleted DIC as a consequence of elevated organic matter remineralization (Jiang et al., 2007). Moreover, the inferred extensive remineralization of organic carbon is supported by a dramatic decrease from high TOC values during the uppermost occurrence of Cloudina to low TOC concentrations at the onset of NE2. The nutrient-driven eutrophication of surface waters (due to high weathering rates) associated with an anoxic overturn is supported by ${ }^{87} \mathrm{Sr} /{ }^{86} \mathrm{Sr}$ analyses of other NeoproterozoicCambrian sections (Shields, 2007). Furthermore the positive $\mathrm{Ce} / \mathrm{Ce}^{*}$ anomaly indicative of suboxic to euxinic water con- 


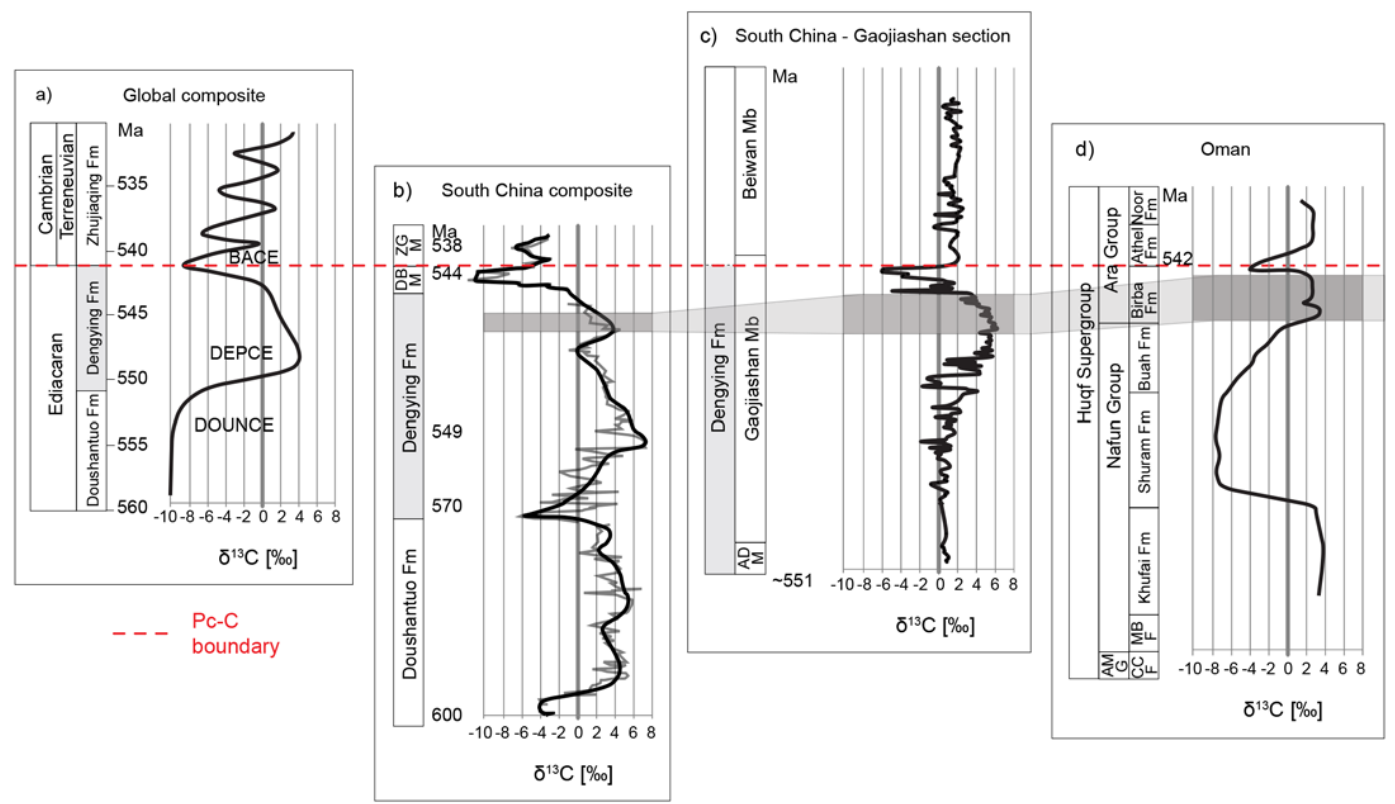

Figure 5. Proposed chemo- and biostratigraphical correlation of $\delta^{13} \mathrm{C}$ profiles from Precambrian-Cambrian boundary intervals at different scales. (a) Global-scale composite (Shields-Zhou and Zhu, 2013), (b) South China composite - Yangtze platform (Zhu et al., 2003), (c) South China (Shaanxi Province), Gaojiashan section (this study), and (d) Oman - South Oman Salt Basin (Amthor et al., 2003). The stratigraphic occurrence of Cloudina below the negative $\delta^{13} \mathrm{C} \mathrm{Pc}-\mathrm{C}$ boundary excursion and its association with a positive $\delta^{13} \mathrm{C}$ interval (grey shaded bar) supports the correlation and indicates a high degree of similarity between the isotopic data sets. We suggest the prominent excursion NE2 at the Gaojiashan section to be a likely equivalent in shape and magnitude to the worldwide negative excursion in $\delta^{13} \mathrm{C}$ at the Pc-C boundary. Following Zhu et al. (2003) and Amthor et al. (2003), we place the Precambrian-Cambrian boundary shortly above the negative $\delta^{13} \mathrm{C}$ peak. Note that the scale at Gaojiashan section is not equal in all columns and strata thicknesses are not time-equivalent. Columns are graphically slightly modified. DBM: Daibu Member; ZGM: Zhangyicun Member; ADM: Algal Dolomite Member; AMG: Abu Mahara Group; CCF: Cap Carbonate Formation; MBF: Masirah Bay Formation.

ditions (German et al., 1991) is consistent with Pc-C REE data of India (Mazumdar et al., 1999) and strengthens an oceanic anoxia scenario. Upwelling of possibly euxinic water masses from greater depths near the platform margin to near-surface environments occurred at least episodically during the Pc-C boundary interval in transitional platform settings (Goldberg et al., 2007; Wille et al., 2008; Och et al., 2013), a situation which agrees well with the data set at Gaojiashan.

A temporal and local change in the carbon turnover cycle proposed by Guo et al. (2012) causing the negative $\delta^{13} \mathrm{C}$ excursion at the Gaojiashan section cannot entirely be excluded. The rapid shift of the negative $\delta^{13} \mathrm{C}$ peak near a lithological contact may indicate a semi-restricted basin setting with intermittent water exchange for which the Black Sea and the Baltic Sea serve as modern analogues. Restricted access to the open ocean would have limited water circulation within the isolated basin. The consequent emerging stratification of water masses would have generated anoxic water masses similar to those described above and resulted in similar isotopic patterns. Nevertheless, the approximately simultaneous evolution, distribution and extinction of the global genus Cloudina argue against a restricted environment at least during the positive $\delta^{13} \mathrm{C}$ excursion. Whether the negative $\delta^{13} \mathrm{C}$ excursion documented in the arkose of the upper part of the Gaojiashan Member is associated with a terminal Ediacaran interval of increased erosion or even a glaciation (the so-called Baykonurian glaciation; Chumakov, 2009, 2011) is speculative. We consider the first theory (global anoxia model) most plausible.

The Gaojiashan section is the first section in Shaanxi Province to record high-resolution stable isotope analyses directly associated with well-documented terminal Ediacaran fossil assemblages. Pending confirmation, this is the first isotopic data set reporting the Pc-C boundary interval in southern Shaanxi Province.

\section{Conclusions}

Chemostratigraphy is a powerful correlation tool to address the uncertain and highly variable litho- and biostratigraphical correlation of late Ediacaran strata at the northern margin of the South China platform. New high-resolution $\mathrm{C}$ - and O-isotopic data as well as TOC concentrations of shallowwater deposits at Gaojiashan section in combination with the detailed palaeontological record (Weber et al., 2007; Guo et 
Table 1. Results of carbonate carbon $\left(\delta^{13} \mathrm{C}\right)$ and oxygen $\left(\delta^{18} \mathrm{O}\right)$ isotopic compositions as well as total organic carbon (TOC) concentration of samples from the Gaojiashan section $(\mathrm{Gj})$.

\begin{tabular}{|c|c|c|c|c|}
\hline Sample & $\begin{array}{r}\text { Distance } \\
{[\mathrm{m}]}\end{array}$ & $\begin{array}{l}\delta^{13} \mathrm{C}[\% \circ] \\
\text { vs. VPDB }\end{array}$ & $\begin{array}{l}\delta^{18} \mathrm{O}[\% \circ] \\
\text { vs. VPDB }\end{array}$ & $\begin{array}{r}\text { TOC } \\
{[\%]}\end{array}$ \\
\hline \multicolumn{5}{|c|}{ Gaojiashan section } \\
\hline $\mathrm{Gj}$ & -3.6 & 0.9 & -2.5 & \\
\hline $\mathrm{Gj}$ & -3.3 & 0.8 & -0.1 & \\
\hline $\mathrm{Gj}$ & -3.0 & 1.0 & -0.8 & 0.003 \\
\hline $\mathrm{Gj}$ & -2.6 & 1.1 & -1.8 & 0.003 \\
\hline $\mathrm{Gj}$ & -2.0 & 0.8 & -2.7 & \\
\hline $\mathrm{Gj}$ & -1.6 & 0.6 & -3.5 & \\
\hline $\mathrm{Gj}$ & -1.3 & 0.6 & -1.4 & 0.004 \\
\hline $\mathrm{Gj}$ & -1.0 & 0.6 & -3.1 & 0.013 \\
\hline $\mathrm{Gj}$ & -0.6 & 0.5 & -1.6 & \\
\hline $\mathrm{Gj}$ & -0.3 & 0.3 & -3.0 & 0.015 \\
\hline $\mathrm{Gj}$ & 2.3 & 0.8 & -2.0 & 0.004 \\
\hline $\mathrm{Gj}$ & 7.0 & & & 0.089 \\
\hline $\mathrm{Gj}$ & 8.0 & & & 0.089 \\
\hline $\mathrm{Gj}$ & 8.6 & 0.3 & -0.2 & 0.004 \\
\hline $\mathrm{Gj}$ & 9.5 & 0.1 & -0.4 & 0.002 \\
\hline $\mathrm{Gj}$ & 10.3 & 0.7 & -0.7 & 0.003 \\
\hline $\mathrm{Gj}$ & 10.6 & 0.7 & -0.9 & 0.002 \\
\hline $\mathrm{Gj}$ & 11.0 & 0.9 & & 0.006 \\
\hline $\mathrm{Gj}$ & 12.6 & -0.8 & -3.7 & 0.049 \\
\hline $\mathrm{Gj}$ & 13.0 & -0.1 & -5.3 & 0.019 \\
\hline $\mathrm{Gj}$ & 13.3 & 0.8 & -4.5 & \\
\hline $\mathrm{Gj}$ & 13.6 & 0.6 & -4.0 & 0.009 \\
\hline $\mathrm{Gj}$ & 14.3 & 0.9 & & \\
\hline $\mathrm{Gj}$ & 14.6 & 0.5 & & \\
\hline $\mathrm{Gj}$ & 15.6 & 0.3 & & 0.103 \\
\hline $\mathrm{Gj}$ & 16.3 & 1.2 & -4.8 & 0.021 \\
\hline $\mathrm{Gj}$ & 17.6 & 0.7 & & \\
\hline $\mathrm{Gj}$ & 18.0 & -0.1 & & \\
\hline $\mathrm{Gj}$ & 18.3 & 0.0 & & 0.013 \\
\hline $\mathrm{Gj}$ & 18.6 & -0.1 & -8.6 & \\
\hline $\mathrm{Gj}$ & 19.0 & 0.2 & -6.2 & 0.005 \\
\hline $\mathrm{Gj}$ & 19.3 & -0.3 & & 0.012 \\
\hline $\mathrm{Gj}$ & 19.6 & 0.6 & & 0.007 \\
\hline $\mathrm{Gj}$ & 20.0 & 1.2 & -6.6 & 0.006 \\
\hline $\mathrm{Gj}$ & 20.3 & -0.9 & & 0.008 \\
\hline $\mathrm{Gj}$ & 20.6 & 1.2 & & 0.017 \\
\hline $\mathrm{Gj}$ & 21.0 & 0.9 & & 0.011 \\
\hline $\mathrm{Gj}$ & 21.3 & 0.4 & & \\
\hline $\mathrm{Gj}$ & 21.6 & -1.9 & -7.5 & 0.033 \\
\hline $\mathrm{Gj}$ & 22.0 & 0.7 & -6.0 & \\
\hline $\mathrm{Gj}$ & 22.3 & 0.8 & & \\
\hline $\mathrm{Gj}$ & 22.6 & 1.0 & & 0.011 \\
\hline $\mathrm{Gj}$ & 23.3 & 1.7 & & 0.015 \\
\hline $\mathrm{Gj}$ & 24.0 & 1.5 & & 0.009 \\
\hline $\mathrm{Gj}$ & 24.3 & 1.3 & & \\
\hline $\mathrm{Gj}$ & 24.6 & 0.6 & & 0.009 \\
\hline $\mathrm{Gj}$ & 25.0 & 1.3 & & 0.012 \\
\hline $\mathrm{Gj}$ & 25.3 & 1.0 & -6.6 & 0.017 \\
\hline $\mathrm{Gj}$ & 25.5 & 0.8 & -7.1 & \\
\hline $\mathrm{Gj}$ & 26.0 & 1.8 & & 0.012 \\
\hline $\mathrm{Gj}$ & 26.3 & 1.0 & & 0.012 \\
\hline $\mathrm{Gj}$ & 26.6 & -0.4 & -7.5 & \\
\hline $\mathrm{Gj}$ & 27.0 & 1.3 & -6.5 & 0.017 \\
\hline
\end{tabular}

Table 1. Continued.

\begin{tabular}{|c|c|c|c|c|}
\hline Sample & $\begin{array}{r}\text { Distance } \\
{[\mathrm{m}]}\end{array}$ & $\begin{array}{l}\delta^{13} \mathrm{C}[\% o] \\
\text { vs. VPDB }\end{array}$ & $\begin{array}{l}\delta^{18} \mathrm{O}[\% o] \\
\text { vs. VPDB }\end{array}$ & $\begin{array}{r}\text { TOC } \\
{[\%]}\end{array}$ \\
\hline \multicolumn{5}{|c|}{ Gaojiashan section } \\
\hline $\mathrm{Gj}$ & 27.3 & 1.3 & & 0.017 \\
\hline $\mathrm{Gj}$ & 27.6 & 2.3 & & 0.015 \\
\hline $\mathrm{Gj}$ & 28.3 & 2.0 & & 0.009 \\
\hline $\mathrm{Gj}$ & 28.6 & -0.7 & & 0.025 \\
\hline $\mathrm{Gj}$ & 29.0 & 1.0 & -6.6 & 0.015 \\
\hline $\mathrm{Gj}$ & 30.0 & 2.0 & & 0.015 \\
\hline $\mathrm{Gj}$ & 31.3 & 2.6 & -5.5 & 0.020 \\
\hline $\mathrm{Gj}$ & 31.6 & 3.0 & -5.7 & 0.014 \\
\hline $\mathrm{Gj}$ & 32.0 & 4.1 & & 0.014 \\
\hline $\mathrm{Gj}$ & 32.3 & 3.2 & & 0.012 \\
\hline $\mathrm{Gj}$ & 32.6 & 2.7 & -6.0 & 0.014 \\
\hline $\mathrm{Gj}$ & 33.0 & -1.7 & & 0.059 \\
\hline $\mathrm{Gj}$ & 33.6 & 0.2 & -7.3 & 0.041 \\
\hline $\mathrm{Gj}$ & 34.6 & -1.2 & & 0.070 \\
\hline $\mathrm{Gj}$ & 35.0 & -0.8 & -7.8 & 0.028 \\
\hline $\mathrm{Gj}$ & 35.3 & 0.9 & & \\
\hline $\mathrm{Gj}$ & 35.6 & 4.3 & -4.9 & \\
\hline $\mathrm{Gj}$ & 36.0 & 4.3 & -5.8 & 0.021 \\
\hline $\mathrm{Gj}$ & 36.3 & 4.3 & & \\
\hline $\mathrm{Gj}$ & 37.0 & 2.3 & & \\
\hline $\mathrm{Gj}$ & 37.3 & 4.5 & & \\
\hline $\mathrm{Gj}$ & 37.6 & 1.6 & -7.3 & 0.046 \\
\hline $\mathrm{Gj}$ & 37.7 & 0.6 & -5.2 & \\
\hline $\mathrm{Gj}$ & 38.0 & 3.8 & -5.5 & 0.020 \\
\hline $\mathrm{Gj}$ & 38.3 & 3.0 & -7.6 & \\
\hline $\mathrm{Gj}$ & 38.6 & 0.9 & -7.8 & 0.058 \\
\hline $\mathrm{Gj}$ & 39.0 & 4.6 & -5.5 & 0.016 \\
\hline $\mathrm{Gj}$ & 39.3 & 5.7 & -5.6 & 0.074 \\
\hline $\mathrm{Gj}$ & 39.6 & 5.2 & -5.0 & \\
\hline $\mathrm{Gj}$ & 40.0 & 3.8 & -8.8 & 0.046 \\
\hline $\mathrm{Gj}$ & 40.3 & 5.1 & -5.3 & \\
\hline $\mathrm{Gj}$ & 40.6 & 5.7 & -6.5 & \\
\hline $\mathrm{Gj}$ & 41.0 & 4.6 & & 0.045 \\
\hline $\mathrm{Gj}$ & 41.3 & 5.3 & -5.6 & \\
\hline $\mathrm{Gj}$ & 42.0 & 5.4 & -5.3 & 0.029 \\
\hline $\mathrm{Gj}$ & 42.3 & 5.1 & & 0.025 \\
\hline $\mathrm{Gj}$ & 42.6 & 5.6 & -5.6 & \\
\hline $\mathrm{Gj}$ & 43.0 & 5.5 & -6.3 & 0.057 \\
\hline $\mathrm{Gj}$ & 43.3 & 5.3 & -7.0 & \\
\hline $\mathrm{Gj}$ & 43.6 & 5.6 & -6.0 & \\
\hline $\mathrm{Gj}$ & 44.0 & 5.3 & & 0.051 \\
\hline $\mathrm{Gj}$ & 44.3 & 4.4 & -6.1 & \\
\hline $\mathrm{Gj}$ & 45.0 & 6.2 & & 0.088 \\
\hline $\mathrm{Gj}$ & 45.3 & 6.2 & -6.1 & \\
\hline $\mathrm{Gj}$ & 45.5 & 5.6 & -6.0 & \\
\hline $\mathrm{Gj}$ & 46.0 & 6.0 & -5.7 & 0.012 \\
\hline $\mathrm{Gj}$ & 46.3 & 5.9 & -6.2 & \\
\hline $\mathrm{Gj}$ & 46.6 & 5.3 & -5.4 & \\
\hline $\mathrm{Gj}$ & 47.3 & 5.5 & -5.3 & \\
\hline $\mathrm{Gj}$ & 47.6 & 5.6 & -5.5 & \\
\hline $\mathrm{Gj}$ & 48.0 & 4.5 & -5.7 & \\
\hline $\mathrm{Gj}$ & 48.3 & 5.4 & -5.2 & \\
\hline $\mathrm{Gj}$ & 48.6 & 4.9 & -5.1 & \\
\hline $\mathrm{Gj}$ & 49.0 & 5.3 & -5.8 & 0.011 \\
\hline $\mathrm{Gj}$ & 49.3 & 5.3 & -5.5 & \\
\hline $\mathrm{Gj}$ & 49.6 & 4.6 & -5.5 & \\
\hline
\end{tabular}


Table 1. Continued.

\begin{tabular}{|c|c|c|c|c|}
\hline Sample & $\begin{array}{r}\text { Distance } \\
{[\mathrm{m}]}\end{array}$ & $\begin{array}{l}\delta^{13} \mathrm{C}[\% \circ] \\
\text { vs. VPDB }\end{array}$ & $\begin{array}{l}\delta^{18} \mathrm{O}[\% \circ] \\
\text { vs. VPDB }\end{array}$ & $\begin{array}{r}\text { TOC } \\
{[\%]}\end{array}$ \\
\hline \multicolumn{5}{|c|}{ Gaojiashan section } \\
\hline $\mathrm{Gj}$ & 50.0 & 4.1 & & 0.060 \\
\hline $\mathrm{Gj}$ & 50.3 & 4.3 & -4.6 & \\
\hline $\mathrm{Gj}$ & 50.6 & 2.8 & -6.9 & \\
\hline $\mathrm{Gj}$ & 51.0 & 4.0 & -5.8 & 0.076 \\
\hline $\mathrm{Gj}$ & 51.3 & 2.4 & -6.5 & \\
\hline $\mathrm{Gj}$ & 51.6 & 3.9 & -3.3 & \\
\hline $\mathrm{Gj}$ & 52.0 & 3.6 & -4.1 & \\
\hline $\mathrm{Gj}$ & 52.3 & 3.5 & -2.7 & \\
\hline $\mathrm{Gj}$ & 52.6 & 3.0 & -4.7 & \\
\hline $\mathrm{Gj}$ & 53.0 & -4.9 & -6.8 & 0.012 \\
\hline $\mathrm{Gj}$ & 53.3 & 0.4 & -7.7 & \\
\hline $\mathrm{Gj}$ & 53.6 & 1.4 & -3.6 & \\
\hline $\mathrm{Gj}$ & 54.0 & -0.8 & -6.1 & 0.008 \\
\hline $\mathrm{Gj}$ & 54.6 & 1.6 & -7.7 & \\
\hline $\mathrm{Gj}$ & 55.0 & 0.8 & -7.1 & 0.001 \\
\hline $\mathrm{Gj}$ & 55.3 & 0.3 & -7.0 & \\
\hline $\mathrm{Gj}$ & 56.0 & -3.9 & -7.4 & 0.020 \\
\hline $\mathrm{Gj}$ & 56.3 & -3.8 & -9.7 & \\
\hline $\mathrm{Gj}$ & 56.6 & -3.3 & -8.9 & \\
\hline $\mathrm{Gj}$ & 57.0 & -6.0 & -8.0 & 0.006 \\
\hline $\mathrm{Gj}$ & 58.0 & -0.8 & -7.2 & 0.003 \\
\hline $\mathrm{Gj}$ & 58.6 & 1.4 & -5.1 & 0.012 \\
\hline $\mathrm{Gj}$ & 59.0 & & & 0.006 \\
\hline $\mathrm{Gj}$ & 60.0 & & & 0.007 \\
\hline $\mathrm{Gj}$ & 61.6 & 1.7 & & 0.010 \\
\hline $\mathrm{Gj}$ & 62.3 & 1.2 & & 0.016 \\
\hline $\mathrm{Gj}$ & 63.3 & 1.3 & & 0.004 \\
\hline $\mathrm{Gj}$ & 64.0 & 1.6 & & 0.012 \\
\hline $\mathrm{Gj}$ & 64.6 & 2.0 & -2.0 & \\
\hline $\mathrm{Gj}$ & 65.0 & 1.9 & -2.8 & \\
\hline $\mathrm{Gj}$ & 65.3 & 2.0 & -2.6 & \\
\hline $\mathrm{Gj}$ & 65.6 & 1.8 & -2.5 & \\
\hline $\mathrm{Gj}$ & 66.3 & -0.4 & -2.6 & \\
\hline $\mathrm{Gj}$ & 67.0 & 0.3 & -2.3 & 0.006 \\
\hline $\mathrm{Gj}$ & 67.3 & 1.6 & -2.3 & \\
\hline $\mathrm{Gj}$ & 67.6 & 1.9 & -2.5 & \\
\hline $\mathrm{Gj}$ & 68.0 & 1.9 & -2.4 & 0.005 \\
\hline $\mathrm{Gj}$ & 68.3 & 2.1 & -2.1 & \\
\hline $\mathrm{Gj}$ & 68.6 & 2.4 & -1.6 & \\
\hline $\mathrm{Gj}$ & 69.0 & -0.4 & -4.6 & 0.008 \\
\hline $\mathrm{Gj}$ & 69.3 & 1.9 & -2.1 & \\
\hline $\mathrm{Gj}$ & 69.6 & 2.2 & -2.5 & \\
\hline $\mathrm{Gj}$ & 70.3 & 2.6 & -2.1 & \\
\hline $\mathrm{Gj}$ & 70.6 & 2.3 & -2.4 & \\
\hline $\mathrm{Gj}$ & 71.0 & 1.5 & & 0.010 \\
\hline $\mathrm{Gj}$ & 71.3 & 1.1 & -2.9 & \\
\hline $\mathrm{Gj}$ & 72.0 & 2.3 & -4.4 & \\
\hline $\mathrm{Gj}$ & 72.3 & 2.0 & -4.0 & \\
\hline $\mathrm{Gj}$ & 72.6 & 1.3 & -4.0 & \\
\hline $\mathrm{Gj}$ & 73.0 & 1.5 & -3.2 & \\
\hline $\mathrm{Gj}$ & 73.3 & 0.0 & -4.1 & \\
\hline $\mathrm{Gj}$ & 73.6 & 1.6 & -3.4 & \\
\hline $\mathrm{Gj}$ & 74.0 & 1.5 & -3.2 & \\
\hline $\mathrm{Gj}$ & 74.3 & 1.4 & -3.1 & \\
\hline $\mathrm{Gj}$ & 74.6 & 1.2 & -3.3 & \\
\hline $\mathrm{Gj}$ & 75.0 & 1.4 & -2.7 & \\
\hline
\end{tabular}

Table 1. Continued.

\begin{tabular}{|c|c|c|c|c|}
\hline Sample & $\begin{array}{r}\text { Distance } \\
{[\mathrm{m}]}\end{array}$ & $\begin{array}{l}\delta^{13} \mathrm{C}[\% o] \\
\text { vs. VPDB }\end{array}$ & $\begin{array}{l}\delta^{18} \mathrm{O}[\% o] \\
\text { vs. VPDB }\end{array}$ & $\begin{array}{r}\text { TOC } \\
{[\%]}\end{array}$ \\
\hline \multicolumn{5}{|c|}{ Gaojiashan section } \\
\hline $\mathrm{Gj}$ & 75.3 & 0.8 & -4.4 & \\
\hline $\mathrm{Gj}$ & 75.6 & 1.1 & -2.8 & \\
\hline $\mathrm{Gj}$ & 76.0 & 0.6 & -8.0 & \\
\hline $\mathrm{Gj}$ & 76.3 & 0.6 & -8.7 & \\
\hline $\mathrm{Gj}$ & 76.6 & 0.7 & -7.8 & \\
\hline $\mathrm{Gj}$ & 77.0 & 1.7 & -7.7 & \\
\hline $\mathrm{Gj}$ & 77.3 & 1.7 & -3.7 & \\
\hline $\mathrm{Gj}$ & 79.0 & 1.8 & -1.5 & \\
\hline $\mathrm{Gj}$ & 79.6 & 1.8 & -5.7 & \\
\hline $\mathrm{Gj}$ & 80.3 & 2.0 & -2.6 & \\
\hline $\mathrm{Gj}$ & 81.3 & 2.2 & -5.5 & \\
\hline $\mathrm{Gj}$ & 81.6 & 2.1 & -5.7 & \\
\hline $\mathrm{Gj}$ & 83.0 & 2.3 & -4.4 & \\
\hline $\mathrm{Gj}$ & 83.3 & 1.9 & & \\
\hline $\mathrm{Gj}$ & 83.6 & 1.3 & -2.6 & \\
\hline $\mathrm{Gj}$ & 84.3 & 2.3 & -4.0 & \\
\hline $\mathrm{Gj}$ & 84.6 & 2.2 & -4.8 & \\
\hline $\mathrm{Gj}$ & 85.3 & 1.4 & -1.8 & \\
\hline $\mathrm{Gj}$ & 85.6 & 2.0 & -4.5 & \\
\hline $\mathrm{Gj}$ & 87.0 & 1.6 & -2.1 & \\
\hline $\mathrm{Gj}$ & 87.3 & 2.3 & -2.6 & \\
\hline $\mathrm{Gj}$ & 87.6 & 2.0 & -2.7 & \\
\hline $\mathrm{Gj}$ & 88.0 & 1.8 & -2.8 & \\
\hline $\mathrm{Gj}$ & 88.6 & 1.4 & -3.6 & \\
\hline $\mathrm{Gj}$ & 89.0 & 1.1 & -3.8 & \\
\hline $\mathrm{Gj}$ & 89.3 & 0.8 & -5.8 & \\
\hline $\mathrm{Gj}$ & 89.6 & 1.3 & -5.6 & \\
\hline $\mathrm{Gj}$ & 90.0 & 1.1 & -5.6 & \\
\hline $\mathrm{Gj}$ & 90.3 & 0.9 & -4.9 & \\
\hline $\mathrm{Gj}$ & 90.6 & 2.4 & & \\
\hline $\mathrm{Gj}$ & 91.0 & 1.4 & -2.4 & \\
\hline $\mathrm{Gj}$ & 91.6 & 0.5 & -3.2 & \\
\hline $\mathrm{Gj}$ & 92.0 & 0.7 & -1.6 & \\
\hline $\mathrm{Gj}$ & 92.3 & 2.1 & -6.0 & \\
\hline $\mathrm{Gj}$ & 92.6 & 1.4 & & \\
\hline $\mathrm{Gj}$ & 93.0 & 1.3 & & \\
\hline $\mathrm{Gj}$ & 93.3 & 1.6 & -6.2 & \\
\hline
\end{tabular}

al., 2012; Meyer et al., 2012; Cai et al., 2013) allowed us to correlate and reconstruct late Ediacaran palaeoenvironmental conditions of the northern Yangtze platform. The identification of a large negative $\delta^{13} \mathrm{C}$ excursion (NE2 to $-6 \%$ ) in the upper Gaojiashan Member (Dengying Formation) together with the directly preceding extinction of Cloudina strongly argues for the Pc-C boundary near the top of the Gaojiashan Member. The overlying Beiwan Member of the Dengying Formation would thus be of earliest Cambrian age. Gaojiashan data can be readily and globally correlated to other Pc-C boundary sections on the Yangtze platform and also globally. Palaeoenvironmental implications agree favourably with a global anoxia model suggesting upwelling of anoxic water masses to have dramatically affected the biosphere during the Pc-C transition interval (Cremonese et al., 2014). 
Table 2. REE $+\mathrm{Y}$ concentrations $\left[\mu \mathrm{g} \mathrm{g}^{-1}\right.$ ] of acetic acid leachates from selected samples of the Gaojiashan Member at the Gaojiashan section analysed by ICP-MS. Ce / Ce*, Eu / Eu*, Y / Ho and Pr / Yb ratios are post-Archean Australian Shale (PAAS)-normalized - for calculation of $\mathrm{Ce}$ and $\mathrm{Eu}$ anomalies see Sect. 4.2.

\begin{tabular}{llllllllll}
\hline Sample & Distance $[\mathrm{m}]$ & $\mathrm{Y}$ & $\mathrm{La}$ & $\mathrm{Ce}$ & $\mathrm{Pr}$ & $\mathrm{Nd}$ & $\mathrm{Sm}$ & $\mathrm{Eu}$ & $\mathrm{Gd}$ \\
\hline Gj 56.3 & 56.3 & 6.358 & 2.133 & 6.207 & 0.638 & 3.193 & 0.644 & 0.196 & 0.649 \\
Gj 56.6 & 56.6 & 5.425 & 2.351 & 6.018 & 0.63 & 3.189 & 0.606 & 0.182 & 0.599 \\
Gj 57.0 & 57.0 & 3.242 & 1.558 & 3.459 & 0.352 & 1.748 & 0.343 & 0.119 & 0.343 \\
\hline Sample & & $\mathrm{Tb}$ & $\mathrm{Dy}$ & $\mathrm{Ho}$ & $\mathrm{Er}$ & $\mathrm{Tm}$ & $\mathrm{Yb}$ & $\mathrm{Lu}$ & \\
\hline Gj 56.3 & 56.3 & 0.109 & 0.72 & 0.161 & 0.526 & 0.08 & 0.578 & 0.096 & \\
Gj 56.6 & 56.6 & 0.099 & 0.572 & 0.143 & 0.427 & 0.059 & 0.384 & 0.072 & \\
Gj 57.0 & 57.0 & 0.057 & 0.387 & 0.086 & 0.286 & 0.041 & 0.296 & 0.059 & \\
\hline Sample & & $\mathrm{Ce}_{N} / \mathrm{Ce}_{N} *$ & $\mathrm{Eu}_{N} / \mathrm{Eu}_{N} *$ & $\mathrm{Y}_{N} / \mathrm{Ho}_{N}$ & $\mathrm{Pr}_{N} / \mathrm{Yb}_{N}$ & & & & \\
\hline Gj 56.3 & 56.3 & 1.405 & 1.382 & 1.449 & 0.353 & & & & \\
Gj 56.6 & 56.6 & 1.398 & 1.395 & 1.397 & 0.524 & & & & \\
Gj 57.0 & 57.0 & 1.414 & 1.536 & 1.391 & 0.379 & & & & \\
\hline
\end{tabular}

\section{The Supplement related to this article is available online at doi:10.5194/fr-18-105-2015-supplement.}

Acknowledgements. We thank Quentin Scouflaire, Bernd Weber (Freie Universität Berlin) and Simone Kasemann (Universität Bremen) for valuable consultations and for providing the samples. We thank our Chinese colleagues Maoyan Zhu, Hong-Fei Ling (Nanjing) and Qingjun Guo (Beijing) for enabling and organizing the field trip. The manuscript was greatly improved by the reviews of an anonymous reviewer and Graham Shields-Zhou, for which we are very grateful. We thank Ewgenjia Kuhl, Maria Diedrich, Yannik Steinmann and Hans-Rudolf Knöfler for aid with sample preparation (all Museum für Naturkunde Berlin). This work has benefited from discussions with colleagues of Forschergruppe 736. The study was funded by the German Research Foundation (DFG-FOR 736). Field work was supported by the Natural Science Foundation of South China (NSFC).

Edited by: D. Korn

Reviewed by: G. Shields and one anonymous referee

\section{References}

Amthor, J. E., Grotzinger, J. P., Schröder, S., Bowring, S. A., Ramezani, J., Martin, M. W., and Matter, A.: Extinction of Cloudina and Namacalathus at the Precambrian-Cambrian boundary in Oman, Geology, 31, 431-434, 2003.

Bau, M. and Dulski, P.: Distribution of yttrium and rare-earth elements in the Penge and Kuruman iron-formations, Transvaal Supergroup, South Africa, Precambrian Res., 79, 37-55, 1996.

Boggiani, P. C., Gaucher, C., Sial, A. N., Babinski, M., Simon, C. M., Riccomini, C., Ferreira, V. P., and Fairchild, T. R.: Chemostratigraphy of the Tamengo Formation (Corumbá Group,
Brazil): A contribution to the calibration of the Ediacaran carbonisotope curve, Precambrian Res., 182, 382-401, 2010.

Brasier, M. D., Rozanov, A. Y., Zhuravlev, A. Y., Corfield, R. M., and Derry, L. A.: A carbon-isotope reference scale for the Lower Cambrian succession in Siberia - Report of IGCP project-303, Geol. Mag., 131, 767-783, 1994.

Brasier, M. D., Shields, G., Kuleshov, V. N., and Zhegallo, E. A.: Integrated chemo- and biostratigraphic calibration of early animal evolution: Neoproterozoic-early Cambrian of southwest Mongolia, Geol. Mag., 133, 445-485, 1996.

Cai, Y., Hua, H., Xiao, S., Schiffbauer, J. D., and Li, P.: Biostratinomy of the late Ediacaran pyritized Gaojiashan Lagerstätte from Southern Shaanxi, South China: Importance of event deposits, Palaios, 25, 487-506, 2010.

Cai, Y., Schiffbauer, J. D., Hua, H., and Xiao, S.: Morphology and paleoecology of the late Ediacaran tubular fossil Conotubus hemiannulatus from the Gaojiashan Lagerstätte of southern Shaanxi Province, South China, Precambrian Res., 191, 46-57, 2011.

Cai, Y., Schiffbauer, J. D., Hua, H., and Xiao, S.: Preservational modes in the Ediacaran Gaojiashan Lagerstatte: Pyritization, aluminosilicification, and carbonaceous compression, Palaeogeogr. Palaeocl., 326, 109-117, 2012.

Cai, Y., Hua, H., and Zhang, X.: Tube construction and life mode of the late Ediacaran tubular fossil Gaojiashania cyclus from the Gaojiashan Lagerstätte, Precambrian Res., 224, 255-267, 2013.

Cai, Y., Hua, H., Schiffbauer, J. D., Sun, B., and Yuan, X.: Tube growth patterns and microbial mat-related lifestyles in the Ediacaran fossil Cloudina, Gaojiashan Lagerstätte, South China, Gondwana Res., 25, 1008-1018, 2014.

Canfield, D. E., Poulton, S. W., Knoll, A. H., Narbonne, G. M., Ross, G., Goldberg, T., and Strauss, H.: Ferruginous conditions dominated later Neoproterozoic deep-water chemistry, Science, 321, 949-952, 2008.

Chumakov, N. M.: The Baykonurian Glaciohorizon of the Late Vendian: Stratigr. Geo. Correl., 17, 373-381, 2009. 
Chumakov, N. M.: Glacial deposits of the Baykonur Formation, Kazakhstan and Kyrgyzstan: Geological Society, London, Memoirs, 36, 303-307, 2011.

Condon, D., Zhu, M., Bowring, S., Wang, W., Yang, A., and Jin, Y.: U-Pb Ages from the Neoproterozoic Doushantuo Formation, China, Science, 308, 95-98, 2005.

Corsetti, F. A. and Kaufman, A. J.: Stratigraphic investigations of carbon isotope anomalies and Neoproterozoic ice ages in Death Valley, California, Geol. Soc. Am. Bull., 115, 916-932, 2003.

Cremonese, L., Shields-Zhou, G. A., Struck, U., Ling, H.-F., and Och, L. M.: Nitrogen and organic carbon isotope stratigraphy of the Yangtze Platform during the Ediacaran-Cambrian transition in South China, Palaeogeogr. Palaeocl., 398, 165-186, 2014.

Derry, L. A.: A burial diagenesis origin for the Ediacaran ShuramWonoka carbon isotope anomaly, Earth Planet. Sc. Lett., 294, 152-162, 2010.

Dulski, P.: Interferences of oxide, hydroxide and chloride analyte species in the determination of rare-earth elements in geological samples by inductively-coupled plasma-mass spectrometry, Fresen. J. Anal. Chem., 350, 194-203, 1994.

Fike, D. A., Grotzinger, J. P., Pratt, L. M., and Summons, R. E.: Oxidation of the Ediacaran Ocean, Nature, 444, 744-747, 2006.

German, C. R., Holliday, B. P., and Elderfield, H.: Redox cycling of rare-earth elements in the suboxic zone of the black-sea, Geochim. Cosmochim. Ac., 55, 3553-3558, 1991.

Germs, G. J.: New shelly fossils from the Nama Group, South-West Africa, Am. J. Sci., 272, 752-761, 1972.

Goldberg, T., Strauss, H., Guo, Q., and Liu, C.: Reconstructing marine redox conditions for the Early Cambrian Yangtze Platform: Evidence from biogenic sulphur and organic carbon isotopes, Palaeogeogr. Palaeocl., 254, 175-193, 2007.

Grotzinger, J. P., Watters, W., and Knoll, A. H.: Calcareous metazoans in thrombolitic bioherms of the terminal Proterozoic Nama Group, Namibia, Paleobiology, 26, 334-359, 2000.

Guo, Q., Strauss, H., Liu, C., Goldberg, T., Zhu, M., Pi, D., Heubeck, C., Vernhet, E., Yang, X., and Fu, P.: Carbon isotopic evolution of the terminal Neoproterozoic and early Cambrian: Evidence from the Yangtze Platform, South China: Palaeogeogr. Palaeocl., 254, 140-157, 2007.

Guo, Q., Deng, Y., and Yang, X.: Carbon Isotopic Evolution of the Late Ediacaran Gaojiashan Biota on the Northern Yangtze Platform, South China, Acta Geol. Sin.-Engl., 86, 1447-1454, 2012.

Halverson, G. P., Dudas, F. O., Maloof, A. C., and Bowring, S. A.: Evolution of the ${ }^{87} \mathrm{Sr} /{ }^{86} \mathrm{Sr}$ composition of Neoproterozoic seawater, Palaeogeogr. Palaeocl., 256, 103-129, 2007.

Hofmann, H. J. and Mountjoy, E. W.: Namacalathus-Cloudina assemblage in Neoproterozoic Miette Group (Byng Formation), British Columbia: Canada's oldest shelly fossils, Geology, 29, 1091-1094, 2001.

Hohl, S. V., Becker, H., Herzlieb, S., and Guo, Q.: Multiproxy constraints on alteration and primary compositions of Ediacaran deep-water carbonate rocks, Yangtze Platform, South China, Geochim. Cosmochim. Ac., 163, 262-278, doi:10.1016/j.gca.2015.04.037, 2015.

Hua, H., Zhang, L.-Y., Zhang, Z.-F., and Wang, J.-P.: Assemblage zones of Gaojiashan Biota and their characteristics, Journal of Stratigraphy, 25, 13-17, 2001.
Hua, H., Pratt, B. R., and Lu-Yi, Z.: Borings in Cloudina Shells: Complex Predator-Prey Dynamics in the Terminal Neoproterozoic, Palaios, 18, 454-459, 2003.

Hua, H., Chen, Z., Yuan, X., Zhang, L., and Xiao, S.: Skeletogenesis and asexual reproduction in the earliest biomineralizing animal Cloudina, Geology, 33, 277-280, 2005.

Hua, H., Chen, Z., and Yuan, X.: The advent of mineralized skeletons in Neoproterozoic Metazoa - new fossil evidence from the Gaojiashan Fauna, Geol. J., 42, 263-279, 2007.

Ishikawa, T., Ueno, Y., Komiya, T., Sawaki, Y., Han, J., Shu, D., Li, Y., Maruyama, S., and Yoshida, N.: Carbon isotope chemostratigraphy of a Precambrian/Cambrian boundary section in the Three Gorge area, South China: Prominent global-scale isotope excursions just before the Cambrian Explosion, Gondwana Res., 14, 193-208, 2008.

Ishikawa, T., Ueno, Y., Shu, D., Li, Y., Han, J., Guo, J., Yoshida, N., and Komiya, T.: Irreversible change of the oceanic carbon cycle in the earliest Cambrian: High-resolution organic and inorganic carbon chemostratigraphy in the Three Gorges area, South China, Precambrian Res., 225, 190-208, 2013.

Jiang, G., Kaufmann, A. J., Christie-Blick, N., Zhang, S., and Wu, H.: Carbon isotope variability across the Ediacaran Yangtze platform in South China: Implications for a large surface-to-deep ocean $\delta^{13}$ C gradient, Earth Planet. Sc. Lett., 261, 303-320, 2007.

Kaufman, A. J. and Knoll, A. H.: Neoproterozoic variations in the C-isotopic composition of seawater: stratigraphic and biogeochemical implications, Precambrian Res., 73, 27-49, 1995.

Kaufman, A. J., Jiang, G., Christie-Blick, N., Banerjee, D. M., and Rai, V.: Stable isotope record of the terminal Neoproterozoic Krol platform in the Lesser Himalayas of northern India, Precambrian Res., 147, 156-185, 2006.

Kaufman, A. J., Corsetti, F. A., and Varni, M. A.: The effect of rising atmospheric oxygen on carbon and sulfur isotope anomalies in the Neoproterozoic Johnnie Formation, Death Valley, USA, Chem. Geol., 237, 47-63, 2007.

Knauth, L. P. and Kennedy, M. J.: The late Precambrian greening of the Earth, Nature, 460, 728-732, 2009.

Kontorovich, A. E., Varlamov, A. I., Grazhdankin, D. V., Karlova, G. A., Klets, A. G., Kontorovich, V. A., Saraev, S. V., Terleev, A. A., Belyaev, S. Y., Varaksina, I. V., Efimov, A. S., Kochnev, B. B., Nagovitsin, K. E., Postnikov, A. A., and Filippov, Y. F.: A section of Vendian in the east of West Siberian Plate (based on data from the Borehole Vostok 3), Russ. Geol. Geophys., 49, 932-939, 2008.

Lawrence, M. G. and Kamber, B. S.: The behaviour of the rare earth elements during estuarine mixing-revisited, Mar. Chem., 100, 147-161, 2006.

Li, C., Love, G. D., Lyons, T. W., Fike, D. A., Sessions, A. L., and Chu, X.: A stratified redox model for the Ediacaran Ocean, Science, 328, 80-83, 2010.

Li, D., Ling, H.-F., Jiang, S.-Y., Pan, J.-Y., Chen, Y.-Q., Cai, Y.F., and Feng, H.-Z.: New carbon isotope stratigraphy of the Ediacaran-Cambrian boundary interval from SW China: implications for global correlation, Geol. Mag., 146, 465-484, 2009.

Li, D., Ling, H.-F., Shields-Zhou, G. A., Chen, X., Cremonese, L., Och, L., Thirlwall, M., and Manning, C. J.: Carbon and strontium isotope evolution of seawater across the Ediacaran-Cambrian transition: Evidence from the Xiaotan section, NE Yunnan, South China, Precambrian Res., 225, 128-147, 2013. 
Ling, H.-F., Chen, X., Li, D., Wang, D., Shields-Zhou, G. A., and Zhu, M.: Cerium anomaly variations in Ediacaran-earliest Cambrian carbonates from the Yangtze Gorges area, South China: Implications for oxygenation of coeval shallow seawater, Precambrian Res., 225, 110-127, 2013.

Macouin, M., Ader, M., Moreau, M.-G., Poitou, C., Yang, Z., and Sun, Z.: Deciphering the impact of diagenesis overprint on negative $\delta^{13} \mathrm{C}$ excursions using rock magnetism: Case study of Ediacaran carbonates, Yangjiaping section, South China, Earth Planet. Sc. Lett., 351-352, 281-294, 2012.

Mazumdar, A., Banerjee, D. M., Schidlowski, M., and Balaram, V.: Rare-earth elements and stable isotope geochemistry of early Cambrian chert-phosphorite assemblages from the Lower Tal formation of the Krol Belt (Lesser Himalaya, India), Chem. Geol., 156, 275-297, 1999.

McFadden, K. A., Huang, J., Chu, X., Jiang, G., Kaufmann, A. J., Zhou, C., Yuan, X., and Xiao, S.: Pulsed oxidation and biological evolution in the Ediacaran Doushantuo Formation, P. Natl. Acad. Sci. USA, 105, 3197-3202, 2008.

McLennan, S. M.: Rare earth elements in sedimentary rocks: Influence of provenance and sedimentary processes, Rev. Mineral., 21, 169-200, 1989.

Meyer, M., Schiffbauer, J. D., Xiao, S., Cai, Y., and Hua, H.: Taphonomy of the upper Ediacaran enigmatic ribbonlike fossil Shaanxilithes, Palaios, 27, 354-372, 2012.

Narbonne, G. M., Myrow, P. M., Landing, E., and Anderson, M. M.: A candidate Stratotype for the Precambrian-Cambrian boundary, Fortune Head, Burin Peninsula, southeastern Newfoundland, J. Earth Sci., 24, 1277-1293, 1987.

Narbonne, G. M., Kaufman, A. J., and Knoll, A. H.: Integrated chemostratigraphy and biostratigraphy of the Windermere Supergroup, northwestern Canada - Implications for Neoproterozoic correlations and the early evolution of animals, Geol. Soc. Am. Bull., 106, 1281-1292, 1994.

Northdurft, L. D., Webb, G. E., and Kamber, B. S.: Rare earth element geochemistry of Late Devonian reefal carbonates, Canning Basin, Western Australia: Confirmation of a seawater REE proxy in ancient limestones, Geochim. Cosmochim. Ac., 68, 263-283, 2004

Och, L. M., Shields-Zhou, G. A., Poulton, S. W., Manning, C., Thirlwall, M. F., Li, D., Chen, X., Ling, H., Osborn, T., and Cremonese, L.: Redox changes in Early Cambrian black shales at Xiaotan section, Yunnan Province, South China, Precambrian Res., 225, 166-189, 2013.

Ohnemueller, F., Meixner, A., Gamper, A., and Kasemann, S. A.: Ocean-Ph Evolution and Weathering Conditions during the Ediacaran: Insights from B, Sr \& Li Isotopes at the Gaojiashan Section, South China, Mineral. Mag., 77, 1881, 2013.

Sawaki, Y., Tahata, M., Ohno, T., Komiya, T., Hirata, T., Maruyama, S., Han, J., and Shu, D.: The anomalous Ca cycle in the Ediacaran ocean: Evidence from $\mathrm{Ca}$ isotopes preserved in carbonates in the Three Gorges area, South China, Gondwana Res., 25, 1070-1089, 2014.

Shields, G. A.: A normalised seawater strontium isotope curve: possible implications for Neoproterozoic-Cambrian weathering rates and the further oxygenation of the Earth, eEarth, 2, 35-42, doi:10.5194/ee-2-35-2007, 2007.
Shields-Zhou, G. and Zhu, M.: Biogeochemical changes across the Ediacaran-Cambrian transition in South China, Precambrian Res., 225, 1-6, 2013.

Steiner, M., Li, G., Qian, Y., and Zhu, M.: Lower Cambrian Small Shelly Fossils of northern Sichuan and southern Shaanxi (China), and their biostratigraphic importance, Geobios, 37, 259-275, 2004.

Verdel, C., Wernicke, B. P., and Bowring, S. A.: The Shuram and subsequent Ediacaran carbon isotope excursions from southwest Laurentia, and implications for environmental stability during the metazoan radiation, Geol. Soc. Am. Bull., 123, 1539-1559, 2011.

Vernhet, E., Heubeck, C., Zhu, M.-Y., and Zhang, J.-M.: Stratigraphic reconstruction of the Ediacaran Yangtze Platform margin (Hunan Province, China) using a large olistolith, Palaeogeogr. Palaeocl., 254, 123-139, 2007.

Wang, J., Chen, D., Yan, D., Wei, H., and Xiang, L.: Evolution from an anoxic to oxic deep ocean during the Ediacaran-Cambrian transition and implications for bioradiation, Chem. Geol., 306307, 129-138, 2012a.

Wang, W., Zhou, C., Yuan, X., Chen, Z., and Xiao, S.: A pronounced negative $\delta^{13} \mathrm{C}$ excursion in an Ediacaran succession of western Yangtze Platform: A possible equivalent to the Shuram event and its implication for chemostratigraphic correlation in South China, Gondwana Res., 22, 1091-1101, 2012b.

Warren, L. V., Fairchild, T. R., Gaucher, C., Boggiani, P. C., Poiré, D. G., Anelli, L. E., and Inchausti, J. C. G.: Corumbella and in situ Cloudina in association with thrombolites in the Ediacaran Itapucumi Group, Paraguay, Terra Nova, 23, 382-389, 2011.

Weber, B., Steiner, M., and Zhu, M.-Y.: Precambrian-Cambrian trace fossils from the Yangtze Platform (South China) and the early evolution of bilaterian lifestyles, Palaeogeogr. Palaeocl., 254, 328-349, 2007.

Wille, M., Nagler, T. F., Lehmann, B., Schroder, S., and Kramers, J. D.: Hydrogen sulphide release to surface waters at the Precambrian/Cambrian boundary, Nature, 453, 767-769, 2008.

Wood, R. A.: Paleoecology of the earliest skeletal metazoan communities: Implications for early biomineralization, Earth-Sci. Rev., 106, 184-190, 2011.

Yang, J., Sun, W., Wang, Z., Xue, Y., and Tao, X.: Variations in $\mathrm{Sr}$ and $\mathrm{C}$ isotopes and $\mathrm{Ce}$ anomalies in successions from China: evidence for the oxygenation of Neoproterozoic seawater?, Precambrian Res., 93, 215-233, 1999.

Yeghicheyan, D., Carignan, J., Valladon, M., Bouhnik Le Coz, M., Samuel, J., BenBakkar, M., Bruguier, O., Keller, F., Pin, C., Pourtales, S., Hénin, O., Macé, J., Morin, N., Guilmette, C., and Marin, L.: The new carbonate reference material Cal-S: preliminary results, Abs. Geoanal., p. 146, 2003.

Zhou, C. and Xiao, S.: Ediacaran $\delta^{13} \mathrm{C}$ chemostratigraphy of South China, Chem. Geol., 327, 89-108, 2007.

Zhu, M., Zhang, J., Steiner, M., Yang, A., Li, G., and Erdtmann, B. D.: Sinian-Cambrian stratigraphic framework for shallow- to deep-water environments of the Yangtze Platform: an integrated approach, Prog. Nat. Sci., 13, 951-960, 2003.

Zhu, M., Zhang, J., and Yang, A.: Integrated Ediacaran (Sinian) chronostratigraphy of South China, Palaeogeogr. Palaeocl., 254, 7-61, 2007. 